University of Denver

Digital Commons @ DU

Sturm College of Law: Faculty Scholarship

University of Denver Sturm College of Law

2014

\title{
A Case Study of Patent Litigation Transparency
}

Bernard Chao

University of Denver, bchao@law.du.edu

Derigan Silver

Follow this and additional works at: https://digitalcommons.du.edu/law_facpub

Part of the Courts Commons, Intellectual Property Law Commons, Judges Commons, and the Litigation Commons

\section{Recommended Citation}

Bernard Chao \& Derigan Silver, A Case Study in Patent Litigation Transparency, 2014 J. DISP. RESOL. 83 (2014).

This Article is brought to you for free and open access by the University of Denver Sturm College of Law at Digital Commons @ DU. It has been accepted for inclusion in Sturm College of Law: Faculty Scholarship by an authorized administrator of Digital Commons @ DU. For more information, please contact jennifer.cox@du.edu,digcommons@du.edu. 


\section{A Case Study of Patent Litigation Transparency}

\section{Publication Statement}

Copyright is held by the author. User is responsible for all copyright compliance. Originally publihed as Bernard Chao \& Derigan Silver, A Case Study in Patent Litigation Transparency, 2014 J. Disp. Resol. 83 (2014). 


\title{
A Case Study In Patent Litigation Transparency
}

\author{
Bernard Chao and Derigan Silver"
}

"[M]any patent trials ... often contain mountains of sealed exhibits."

\section{INTRODUCTION}

Although the courts have long recognized both a First Amendment and common law right of access to judicial documents, this right is not absolute and parties often seek to have their filings shielded from the public eye. That individuals can hide their health records, or businesses their employee records, is neither surprising nor disturbing. But what may be shocking to some is the extent to which corporations fight their patent lawsuits in almost total secrecy. Large swaths of filings in patent litigations are totally inaccessible. Parties routinely seal court filings, sometimes with little to no judicial oversight. What's more these filings often do not contain any trade secrets.

This practice reduces judicial accountability and is particularly harmful to our patent system. A transparent court system serves the public interest by giving the public an understanding and appreciation of how the judicial system works. Access also provides an important check on the courts, preventing both corruption and incompetence. Public outcry over unjust decisions often leads to reform. There are also patent-specific reasons why greater transparency is beneficial. Open court records make it easier to discern the boundaries of a patent's claims and learn about any validity issues. This information improves the decision making of parties encountering patents, thereby helping the entire patent system to operate more efficiently and effectively.

By focusing on a single high profile patent case, Monsanto v. DuPont, ${ }^{2}$ this article explores the problem of transparency in patent litigation from two perspectives. First, this article provides metries for understanding the nature and quantity of documents that were filed under seal in the Monsanto case. Second, this article scrutinizes particular aspects of the case to provide a more nuanced understanding of what the public cannot see. Although primarily descriptive, this article critically analyzes the sealing of so many documents by questioning the level of judicial oversight applied in decisions to seal court filings. It then goes on to challenge the justifications for sealing many specific documents.

\footnotetext{
* Bernard Chao is an Assistant Professor, University of Denver Sturm College of Law. Derigan Silver is an Associate Professor, Department of Media, Film and Journalism Studies University of Denver. The authors would like to thank Margaret Kwoka for her thoughtful comments and Cindy Goldberg for her tireless work analyzing and coding the docket of the Monsanto case.

1. Order Granting-In-Part and Denying-In-Part Motions to Seal at 3, Apple Inc. v. Samsung Electronics Co. et al., No. 11-CV-01846-LHK, 2012 WL 3536800 (N.D. Cal. Aug. 9, 2012) (discussing the frequency with which courts seal documents in patent cases).

2. Monsanto Co. v. E.I. Dupont DeNemours \& Co., No. 09-CV-00686, 2012 WL 2979080 (E.D. Mo. July 20, 2012).
} 
This article proceeds in four parts. Part I explains why judicial transparency is important both to our democratic system, generally, and to the patent system, specifically. Part II of this article describes the confusing state of the right to access judicial documents in civil cases. Although courts agree that the public has some right to access some court records, the precise contours of these rights are not clear. Different jurisdictions apply different standards to different categories of documents It is also disputed whether the public's right of access is rooted in the First Amendment, common law, or both. While some courts have recognized a broad right of access to judicial documents, and require a compelling reason to seal most documents, other courts determine which documents to seal based on the type of document. ${ }^{3}$

Part III introduces the Monsanto v. DuPont case and explains why it was chosen for this case study. The genetically modified seeds that lay at the heart of the dispute have become a vital part of U.S. agribusiness. Therefore, this litigation generated far more interest than a typical patent case. The case also raised novel damages theories. The defendant, DuPont, had not yet sold any infringing seeds, yet the jury still awarded the plaintiff, Monsanto, $\$ 1$ billion. Such a result clearly warrants further study. Finally, many of the most critical filings and decisions were sealed from public view, making Monsanto $v$. DuPont an ideal patent case to study judicial transparency.

Part IV assesses transparency in the Monsanto case according to several metrics. For example, 592 of the 1,697 of the filings listed in the PACER docket were filed under seal. Additional metrics count the different types of documents filed under seal, and when the judicial process was used to safeguard the public's right to access. Part IV then delves deeper with a qualitative description of some of the sealed Monsanto filings. Specifically, Part IV looks at selected documents filed during the pleading, summary judgment, and trial phases of the litigation.

At the beginning of the Monsanto case, the court used a few procedural safeguards - requiring court approval to file material under seal and the public filing of redacted versions - to ensure a minimal level of transparency. Unfortunately, the parties, and the court only paid lip service to these procedures and later abandoned them entirely. Consequently, as the case progressed through summary judgment, more and more filings were hidden from public view. The court even filed its own orders under seal. This pattern continued as the trial date approached, with motions in limine, jury instructions, and exhibit lists filed completely under seal. Worse yet some of these filings mysteriously disappeared from the docket. However, once the trial began, the court suddenly allowed the public to access the vast majority of the trial transcripts.

Despite this last minute change in course, the Monsanto v. DuPont case paints a grim picture of limited public access to court records. Much of the litigation took place entirely in secret. Many of the key filings and court decisions were filed under seal without any public redacted versions made available. The court made little or no effort to comply with the law's procedural safeguards. Unfortunately, it is unclear what caused this procedural breakdown. The court may simply not have had sufficient resources to review all the applications to seal through-

3. See infra Part II. 
out this massive case. ${ }^{4}$ Whether a result of resource constraints, or another factor, one thing is clear: the Monsanto case highlights the recurring problem of over sealing important documents in patent cases.

\section{THE IMPORTANCE OF JUDICIAL TRANSPARENCY}

\section{A. Generally}

The importance of allowing the public to access court records is discussed in a series of Supreme Court decisions. Beginning with Richmond Newspapers, Inc. v. Virginia, ${ }^{5}$ decided in 1980 , the U.S. Supreme Court consistently held there is a First Amendment right of access to judicial proceedings. ${ }^{6}$ While recent scholarship $^{7}$ and limited case law $^{8}$ suggest that lower courts are increasingly willing to expand a First Amendment right of access to "much broader arenas of access involving other branches and agencies of government," access to government activities and documents is typically only granted by freedom of information statutes, sunshine laws or other federal and state statutes. ${ }^{10}$ Indeed, in his concurring opinion in Richmond Newspapers, Justice John Paul Stevens wrote that the decision represented a landmark First Amendment decision that newsgathering was constitutionally protected." "This is a watershed case. Until today the Court has accorded virtually absolute protection to the dissemination of information or ideas, but never before has it squarely held that the acquisition of newsworthy matter is entitled to any constitutional protection whatsoever." ${ }^{2}$

Although Richmond Newspapers involved a closed murder trial, numerous lower courts have extended the right of access to civil trials as well. Some courts

4. For a discussion of the time and effort required to review an application to seal, see Order Denying Motion to Seal, Apple Inc. v. Samsung Elec. Co. et al., No. 11-CV-01846-LHK (N.D. Cal. Jul. 24, 2012).

5. 448 U.S. $555(1980)$.

6. See, e.g., Press-Enter. Co. v. Riverside Cnty. Super. Ct., 478 U.S. 1 (1986) [hereinafter Press Enterprise I]; Press-Enter. Co. v. Riverside Cnty. Super. Ct., 464 U.S. 501 (1984) [hereinafter Press Enterprise II]; Globe Newspaper Co. v. Super. Ct., 457 U.S. 596 (1982).

7. See, e.g., Matthew D. Bunker \& Clay Calvert, Could Wild Horses Drag Access Away From Courtrooms? Expanding First Amendment Rights to New Pastures, 18 COMM. LAW \& POL'Y 247 (2013) (analyzing how the "experience-and-logic test" used by the Supreme Court in judicial access cases is being applied to other areas of law); Derigan Silver, Power, National Security and Transparency: Judicial Decision Making \& Social Architecture in the Federal Courts, 15 COMM. LAW \& POL'Y $129,156-63$ (2010) (writing that some federal judges have concluded that the First Amendment right of access established in judicial transparency cases might be extendable to other types of cases).

8. See, e.g., Leigh v. Salazar, 677 F.3d 892 (9th Cir. 2012); Cal-Almond, Inc. v. U.S. Dep't of Agric., 960 F.2d 105 (9th Cir. 1992).

9. Bunker \& Calvert, supra note 7 , at 249

10. The federal law governing access to government documents, the Freedom of Information Act, 5 U.S.C. $\S 552(2012)$ is perhaps the best-known law governing access to government information in the United States, although all states have similar statutes governing access to state government documents. The term "sunshine laws" typically refer to open meeting laws at the federal and state level. For a discussion of public access laws across the United States, see Daxton R. "Chip" Stewart, Let the Sunshine in, or Else: An Examination of the "Teeth" of State and Federal Open Meetings and Open Records Laws, 15 COMM. LAW \& POL'Y 265 (2010).

11. Richmond Newspapers, Inc. v. Virginia, 448 U.S. 555, 582 (1980) (Stevens, J., concurring).

12. Id. 
have based this right of access on the First Amendment, ${ }^{13}$ while others have found a common law ${ }^{14}$ or state constitutional basis for public access. ${ }^{15}$ Courts have also extended both the First Amendment right of access and the common law right of access to judicial documents in criminal and civil cases. ${ }^{16}$

The Supreme Court has relied on several rationales for its creation of "an architecture of presumptive access" 17 to the judiciary. Writing for a plurality in Richmond Newspapers, Chief Justice Warren Burger focused on the historic openness of the judicial system and discussed both the functional benefits of transparency and the First Amendment's role in self-governance. Based on these rationales, Chief Justice Burger's opinion held that the First Amendment required that the trial in question be open to the press and public.

Both the language of the First Amendment, and the Court's decision in Gannett Co. v. DePasquale, ${ }^{18}$ one year before its Richmond Newspapers decision, help to explain Chief Justice Burger's rationale. Because the Court had ruled the previous term that there was no constitutional right of access to trials under the Sixth Amendment, the justices had to distinguish Richmond Newspapers by finding a right of access in the First Amendment. ${ }^{19}$ However, the First Amendment is written in negative terms, ${ }^{20}$ mandating what government cannot do, rather than what it must do. The Amendment seems to require the government avoid restricting speech, rather than provide access to government facilities, documents, or proceedings. ${ }^{21}$

Perhaps due to the textual problems with attaching a right of access to the First Amendment, Chief Justice Burger dedicated ten pages of his plurality opinion to a discussion of "the history of criminal trials being presumptively open" and the benefits government openness brings to society. ${ }^{22}$ The plurality also included a functional analysis of transparency in government, discussing the "right of access," the "right to gather information," and the "right to receive information and ideas," all rights that the Chief Justice found in the First Amendment. ${ }^{23}$ Even

13. See, e.g., Associated Press v. New Hampshire, 888 A.2d 1236, 1244 (N.H. 2005) (noting that lower federal courts have applied a First Amendment right of access to civil proceedings).

14. See, e.g., Nixon v. Warner Commc'ns, Inc., 435 U.S. 589, 599 (1978).

15. See, e.g., Publicker Indus., Inc. v. Cohen, 733 F.2d 1059 (3d Cir. 1984) (recognizing both constitutional and common law rights of access to civil proceedings).

16. See, e.g., Press-Enterprise II, 478 U.S. 1, 13 (1986). ("Denying the transcript of a 41-day preliminary hearing would frustrate what we characterized as the 'community therapeutic value' of openness.").

17. Derigan Silver, Media Censorship and Access to Terrorism Trials: A Social Architecture Analysis, 25 NOTRE DAME J.L. ETHICS \& PUB. POL'Y 143, 152 (2011).

18. 443 U.S. 368 (1979).

19. Richmond Newspapers, Inc. v. Virginia, 448 U.S. 555, 581-82 (1980) (White, J., concurring) ("This case would have been unnecessary had [Gannett $]$ construed the Sixth Amendment to forbid excluding the public from criminal proceedings except in narrowly defined circumstances. But the Court there rejected the submission of four of us to this effect, thus requiring that the First Amendment issue involved here be addressed." (emphasis added)).

20. U.S. CONST. amend. I ("Congress shall make no law . . abridging the freedom of speech, or of the press....").

21. For a discussion of newsgathering rights and the debate of the First Amendment's positive requirements and negative restrictions, see generally Erik Ugland, Demarcating the Right to Gather News: A Sequential Interpretation of the First Amendment, 3 DUKE J. CONST. L. \& PUB. POL'Y 113 (2008).

22. Richmond Newspapers, 448 U.S. 555, 564-75 (1980) (plurality).

23. Id. at 576 (plurality). Ultimately, Burger concluded it was not crucial how the right was described. $I d$. 
though the Constitution contains no textual guarantee to attend criminal trials, Chief Justice Burger wrote that some unenumerated fundamental rights were "indispensable to the enjoyment of rights explicitly defined." 24

Two years after Richmond Newspapers, the Court further expanded access to the judiciary under the First Amendment. In Globe Newspaper Co. v. Superior Court, ${ }^{25}$ Justice William Brennan, writing for the majority, employed strict scrutiny in a court-access case for the first time, and elaborated on the structural benefits outlined in Richmond Newspapers. Although the right of access to the judiciary is not explicitly mentioned in the First Amendment, Brennan wrote the original intent of the First Amendment supported a broad constitutional right of access. $^{26}$ The majority cited previous Court decisions that supported a First Amendment right of access, writing that access is necessary to protect the free flow of information about government and to ensure the proper functioning of a democratic society. ${ }^{27}$ Like Chief Justice Burger, Justice Brennan noted both the long history of open judicial proceedings and contended that transparency played a "particularly significant role . . . in the functioning of the judicial process and government as a whole." 28

In 1984, in Press-Enterprise Co. v. Riverside County Superior Court (PressEnterprise I), ${ }^{29}$ the Court ruled that, as an integral element of criminal trials, jury selection was subject to the First Amendment presumption of openness. Writing for the majority of the Court, Chief Justice Burger once again relied upon both historical arguments, ${ }^{30}$ and the structural benefits that openness brings to the judicial system. ${ }^{3}$

In the 1986 case, Press-Enterprise Co. v. Riverside County Superior Court (Press-Enterprise II) ${ }^{32}$ the Court held that the First Amendment presumption of openness extended to criminal pretrial hearings as well. Writing for the majority, Chief Justice Burger again used both historical and structural arguments, formalizing the so-called "experience and logic" test now used to determine if a First Amendment right of access attaches to a judicial proceeding. ${ }^{33}$ The Chief Justice wrote that if a court proceeding was traditionally open to the public, and "public access play[ed] a significant positive role in the functioning of the particular process in question," the proceeding was presumptively open to the public. ${ }^{34}$ Under this analysis, closure is only allowed when, utilizing a heightened scrutiny analy-

24. Id. at 580 .

25. 457 U.S. 596 (1982).

26. Id. at 604 . (" $[\mathrm{T}]$ he Framers were concerned with broad principles, and wrote against a background of shared values and practices. The First Amendment is thus broad enough to encompass those rights that, while not unambiguously enumerated in the very terms of the Amendment, are nonetheless necessary to the enjoyment of other First Amendment rights.").

27. Id. at 604-05 (quoting Mills v. Alabama, 384 U.S. 214, 218 (1966), and citing Thornhill v. Alabama, 310 U.S. 88, 95 (1940); Richmond, 448 U.S. at 587-88 (Brennan, J., concurring); id. at 575 (plurality) ([T]he "'expressly guaranteed freedoms' of the First Amendment 'share a common core purpose of assuring freedom of communication on matters relating to the functioning of government"')).

28. Globe Newspaper Co., 457 U.S. at 606

29. 464 U.S. 501 (1984).

30. $I d$. at $506-08$.

31. Id. at $508-10$.

32. 478 U.S. 1 (1986).

33. Id. at 6-13.

34. Id. at 8 . 
sis, the court finds that a motion to seal rebuts the presumption of access. The presumption of access "may be overcome only by an overriding interest based on findings that closure is essential to preserve higher values and is narrowly tailored to serve that interest." 35

As the Court's opinions reveal, the Supreme Court has consistently held that a transparent judicial system is part of our heritage with roots in colonial America and England, serves an important democratic function, and reinforces the public's faith in the judicial system. ${ }^{36}$ In addition, as in other areas of government, transparency can ensure the proper functioning of the judicial system and prevent corruption and abuses of power. ${ }^{37}$ These benefits are advanced by access to judicial proceedings and judicial documents in both criminal and civil cases. As Judge Richard Posner wrote, "[t]he parties to a lawsuit are not the only people who have a legitimate interest in the record compiled in a legal proceeding." 38

\section{B. Patent Specific}

Open access to court filings is particularly important in patent cases because such access helps give the public notice of patent boundaries. To understand just what a patent protects, it is important to be familiar with the two primary components of a patent, the "specification" and the "claims." The "specification" is the written description of the invention. It describes one or more embodiments (i.e. examples) of the invention and includes explanatory drawings. The claims follow the specification and delineate the scope of the patentee's rights. Each claim contains several limitations that define the claim's attributes. If any claim of patent is infringed (i.e. when an accused product contains all the claim's limitations), the patent is infringed.

Patent law seeks to provide the public with notice of a patentee's property rights by requiring that claims "distinctly point out what the inventor regards as the invention." ${ }^{39}$ Patents are public documents. Ideally, competitors should be able to find relevant patents, read the claims, and determine what technology they can use. $^{40}$ In practice, however, the patent system frequently does not operate this way.

In many industries, companies turn a blind eye to patents. ${ }^{41}$ In part, this is due to the voluminous number of patents that would have to be reviewed. Technology products typically contain many features involving hundreds, if not thousands, of patents. ${ }^{42}$ Moreover, looking at patents often turns out to be a fruitless endeavor.

35. Id. at 9-10 (quoting Press-Enterprise I, 464 U.S. at 510).

36. See, e.g., Richmond Newspapers, Inc. v. Virginia, 448 U.S. 555, 570-71 (1980) (writing that open criminal trials provide "an outlet for community concern[s], hostility and emotion").

37. Republic of the Phil. v. Westinghouse Elec. Corp., 949 F.2d 653, 660-64 (3d Cir. 1991).

38. Citizens First Nat'1 Bank of Princeton v. Cincinnati Ins. Co., 178 F.3d 943, 944 (7th Cir. 1999).

39. 35 U.S.C. $\$ 112$ (b) (2012).

40. See Permutit Co. v. Graver Corp., 284 U.S. 52, 60 (1931) (explaining that a patent must contain claims that "inform the public during the life of the patent of the limits of the monopoly asserted, so that it may be known which features may be safely used or manufactured without a license and which may not.").

41. Mark A. Lemley, Ignoring Patents, 2008 MICH. ST. L. REV. 19, 21 (2008) ("both researchers and companies in component industries simply ignore patents.").

42. For example, Goodman and Myers estimated that there were 6,872 patents and patent applications essential to the Wideband Code Division Multiple Access (WCDMA) and 924 to the CMDA 
Most patent claims are unclear and consequently do not provide effective notice of their boundaries. ${ }^{43}$ These issues are partially due to the difficulty of using words to precisely describe technical inventions. ${ }^{44}$ This problem is exacerbated when patent attorneys deliberately use ambiguous language. ${ }^{45}$ Various studies show that even judges have difficulty agreeing on the meaning of different claims. ${ }^{46}$

This uncertainty burdens innovation in several ways. When a competitor encounters a patent with unclear claims, the competitor may be forced to be unduly cautious. $^{47}$ For example, a company might forego using a particular technology that is not actually covered by a patent, in their product, due to their fear of infringement. More importantly, society loses too. A company's decision to forego using a chosen technology may cause its product to become less desirable or more expensive. Uncertainty may also cause companies to take licenses for patents they do not need. The cost of acquiring such licenses is passed on to consumers, unnecessarily increasing the price they pay for a product. ${ }^{48}$

High transaction costs are also associated with unclear claims. It is expensive to have attorneys conduct patent clearances. ${ }^{49}$ It is even more costly to learn the extent of a patent's reach through litigation..$^{50}$ Additionally, by the time a company learns about a patent, they may have already incurred significant sunk costs. Retooling a product to avoid future infringement often costs far more than designing a non-infringing product in the first instance. ${ }^{51}$

Allowing the public to access judicial records clarifies these boundaries and sheds light on validity issues. When patent holders sue in court, they must explain which aspects of the infringing product their patent claim covers. This involves disclosing infringement contentions and how they interpret the claims. Similarly, defendants try to identify weaknesses in the patent in suit. This includes identifying prior art that might affect the validity of a patent, disclosing invalidity conten-

$20003 \mathrm{G}$ cellular phone standards. David J. Goodman \& Robert A. Myers, 3G Cellular Standards and Patents, 2 (2005), http://eeweb.poly.edu/dgoodman/wirelesscom2005.pdf.

43. See Bernard Chao, The Infringement Continuum, 35 CARDOZO L. REV. 1359, $1372-75$ (2014) (discussing the issue of unclear claims).

44. James Bessen \& Michael J. Meurer, Patent Failure: How Judges, Bureaucrat, and LAWYERS PUT INNOVATORS AT RISK 55 (2008).

45. Dan L. Burk \& Mark A. Lemley, Fence Posts or Sign Posts? Rethinking Patent Claim Construction, 157 U. PA. L. REV. 1743, 1753 (2009) ("[M]any applicants don't specify what they mean by ambiguous technical language, either because they don't think about the issue or because they intend to exploit the ambiguity in obtaining or enforcing the patent.").

46. See David L. Schwartz, Practice Makes Perfect? An Empirical Study of Claim Construction Reversal Rates in Patent Cases, 107 MICH. L. REV. 223, 248 (2008) (finding that in disputes about claim construction, $38.2 \%$ of Federal Circuit decisions disagreed with the district court's claim interpretation of at least one claim term); J. Jonas Anderson \& Peter S. Menell, Informal Deference: An Historical, Empirical, and Normative Analysis of Patent Claim Construction, 108 NW. U. L. REV. 1, 61 (2013) (reporting that reversal rates have subsequently decreased to less than $20 \%$ rate by 2009 ).

47. Federal Trade Comm'n, The Evolving IP Marketplace: Aligning Patent Notice and Remedies with Competition, 78 (2011), available at http:/www.ftc.gov/sites/default/files/documents/reports/ evolving-ip-marketplace-aligning-patent-notice-and-remedies-competition-report-federal-

trade/110307patentreport.pdf [hereinafter FTC, Evolving IP Marketplace].

48. $I d$.

49. BESSEN \& MEURER, supra note 44 , at 55 (noting the $\$ 20,000$ to $\$ 100,000$ cost of legal opinion letters).

50. The median cost of bringing a single patent case to trial ranges from $\$ 650,000$ when the amount at risk is less than $\$ 1,000,000$ to $\$ 5,500,000$ when there is more than $\$ 25,000,000$ at risk. AIPLA Report of the Economic Survey, AM. INTELL. PROP. L. ASS'N 29 (July 2009).

51. FTC, Evolving IP Marketplace, supra note 47, at 225. 
tions and explaining their own interpretation of the claims. Claim interpretation, also known as claim construction, is so important that courts often deal with it separately, in a so-called Markman hearing. ${ }^{52}$ Infringement and validity issues are also usually addressed when the parties file summary judgment motions.

Merely accessing judicial decisions is often insufficient to advance the public interest in judicial transparency. As an initial matter, since most patent cases settle, there are frequently no court rulings that reveal the positions the parties took. ${ }^{53}$ Even if a court does issue a ruling, it will often be vacated. ${ }^{54}$ In these cases, the parties' court filings become even more important. Access to these records can provide the public with a better understanding of both the scope of a patent's claims and the likelihood that a patent is valid. Infringement contentions and claim construction statements provide far greater detail on the purported scope of a patent than that found in a patent's claims. Further, the patentee is potentially estopped from changing its interpretation of claim terms. ${ }^{55}$

The fact that the patent owners often seek to vacate any adverse rulings after settlement also highlights the importance of the parties' filings. ${ }^{56}$ The purpose behind such tactics is to avoid collateral estoppel when asserting the patents in the future. ${ }^{57}$ This suggests that knowing more about litigated patents benefits the public because they will be asserted again. Unfortunately, when courts seal patent litigation filings, the public never sees these benefits.

Because most patent infringement claims are not litigated, ${ }^{58}$ court access does not enhance public notice for the vast majority of patents. However, there is reason to believe that patent suits involve the most important patents. Shawn Miller's study concluded that with the notable exception of software patents, patents that were litigated more than once tended to be of higher quality. ${ }^{59}$ Presumably, these higher quality patents (i.e. patents that are likely to be found valid and have broad claim scope) affect the public most.

52. In Markman v. Westview Instruments, 517 U.S. 370 (1996), the Supreme Court held that claim construction is a matter of law for courts to decide. A majority of courts now hold a hearing to construe the meaning of disputed claims terms "midway through, or before the close of, fact discovery, and prior to expert discovery." Peter S. Menell et AL., PATENT CASE MANAGEMENT Judicial Guide 55 (2nd ed. 2012).

53. See, e.g., Jay Kesan \& Gwendolyn Ball, How Are Patent Cases Resolved? An Empirical Examination of the Adjudication and Settlement of Patent Disputes, 84 WASH. U. L. REV. 237, 273 tbl. 4 (2006) (finding that over $80 \%$ of patent cases are resolved before summary judgment).

54. Jeremy W. Bock, An Empirical Study of Certain Settlement-Related Motions for Vacatur in Patent Cases, 88 IND. L. J. 919 (2013) (discussing how courts routinely grant vacatur of rulings affecting the scope, validity, or enforceability of a patent and thereby strip the ruling of having any preclusive effect.).

55. See generally Moore's Federal Practice $\S 18 \square 134.30$. “[W]here a party assumes a certain position in a legal proceeding, and succeeds in maintaining that position, he may not thereafter, simply because his interests have changed, assume a contrary position, especially if it be to the prejudice of the party who has acquiesced in the position formerly taken by him." New Hampshire v. Maine, 532 U.S. 742, 742-43 (2001) (quoting Davis v. Wakelee, 156 U.S. 680, 689 (1895)).

56. Bock, supra note 54, at 951-52 (reporting such a condition in $22.8 \%$ of settlements).

57. Id. at 922 .

58. See Mark A. Lemley \& Carl Shapiro, Probabilistic Patents, 19 J. ECON. PERSP. 75, 79-83 (2005).

59. See Shawn P. Miller, What's the Connection Between Repeat Litigation and Patent Quality? A (Partial) Defense of the Most Litigated Patents, 16 STAN. TECH. L. REV. 313, 341 (2013). But see, R. Allison, Mark A. Lemley \& Joshua Walker, Patent Quality and Settlement Among Repeat Patent Litigants, 99 GEO. L.J. 677-712 (2011). 


\section{THE PUBLIC'S RIGHT TO ACCESS JUDICIAL RECORDS}

As noted above, numerous courts have found a constitutional or common law right of access to judicial records, ${ }^{60}$ although courts do not always agree about when a First Amendment right applies and when a common law right applies. In addition, many states have statutes guaranteeing access. ${ }^{61}$ Courts have generally ruled that the right of access applies to a wide array of both criminal and civil court records. ${ }^{62}$

As in cases dealing with access to judicial proceedings, courts have used the "experience and logic test" to determine if a First Amendment right of access attaches to judicial documents. Under this test, the court must first determine whether a proceeding or record has historically been open to the public. ${ }^{63}$ Next, the court must determine if transparency plays a "positive role in the functioning of the particular process in question." 64 Closure is only allowed under a heightened scrutiny analysis, and the presumption of access "may be overcome only by an overriding interest based on findings that closure is essential to preserve higher values and is narrowly tailored to serve that interest. ${ }^{" 65}$ Put another way, courts must find a compelling reason to seal documents, and the sealing must be confined to information that advances that reason. In contrast, courts that recognize a common law right of access apply a much less strict balancing approach. Typically this approach weighs the need for confidentiality against the public's strong, presumptive right of access to court proceedings and records. ${ }^{66}$

United States courts have established inconsistent parameters of the right of access to documents involving negotiated settlements, civil discovery, and documents that were never officially filed with the court. Some courts have found a First Amendment or common law right of access to discovery information, ${ }^{67}$ while other courts have not. ${ }^{68}$ Other courts have found the standard for issuing a protec-

60. Some courts have ruled the First Amendment right of access requires a higher standard for sealing a document than the common law right. See, e.g., Lugosch v. Pyramid Co., 435 F.3d 110, 124 (2d Cir. 2006); In re Baltimore Sun Co., 886 F.2d 60, 64 (4th Cir. 1989).

61. See Judicial Records: A Guide to Access in State \& Federal Courts, NEWS MEDIA \& L., Summer 1995 , at 1 .

62. See, e.g., In re Access to Juror Questionnaires, 37 A.3d 879 (D.C. Cir. Jan. 19, 2012) (granting access to questionnaires filled out by jurors and alternates); Associated Press v. United States Dist. Court, 705 F.2d 1143 (9th Cir. 1983) (attaching a First Amendment right of access to pretrial motions and documents); Leucadia, Inc. v. Applied Extrusion Techs, Inc., 998 F.2d 157 (3d Cir. 1993) (granting access to judicial documents in a civil case).

63. Press-Enterprise II, 478 U.S. 1, 8 (1986).

64. Id.

65. Id. at 9-10 (quoting Press-Enterprise I, 464 U.S. at 510). See also, Globe Newspaper Co. v. Superior Court, 457 U.S. 596 606-07 (1982); Washington Post v. Robinson, 935 F.2d 282, 288, 292 (D.C. Cir. 1991); Virginia Dep't of State Police v. Washington Post, 386 F.3d 567, 575 (4th Cir. 2004).

66. Seymour Moskowitz, Discovering Discovery: Non-Party Access to Pretrial Information in the Federal Courts 1938-2006, 78 COLO. L. REV. 817, 861 (2007); Hagestad v. Tragesser, 49 F.3d 1430, 1434 (9th Cir. 1995) (describing an approach that begins with a common law presumption of access to judicial records and then weighs the "public interest in understanding the judicial process" against "whether disclosure of the material could result in improper use."). See also In re National Broadcasting Co., 653 F.2d 609, 612-13 (D.C. Cir. 1981); Miller v. Indiana Hosp., 16 F.3d 549, 551 (3d Cir. 1994).

67. See, e.g., In re Coordinated Pretrial Proceedings in Petroleum Products Antitrust Litigation, 101 F.R.D. 34 (C.D. Cal 1984).

68. See, e.g., In re Reporters Comm. for Freedom of the Press, 773 F.2d 1325 (D.C. Cir. 1985); Tavoulareas v. Washington Post, 724 F.2d 1010 (D.C. Cir 1984). 
tive order to be the "good cause" standard rather than the First Amendment. ${ }^{69}$ The "good cause" standard, based on Rule 26(c) of the Federal Rules of Civil Procedure ${ }^{70}$ and other similar state rules of procedure, requires a party in a civil lawsuit to show good cause as to why documents should be sealed. ${ }^{71}$ Still other courts have ruled that no right of access to discovery materials exists until the trial has begun or the documents have been introduced as evidence. ${ }^{72}$

Further complicating matters is whether unfiled documents are presumptively open to the public. While many courts have refused to recognize a right of access to unfiled documents, ${ }^{73}$ a few judges have declined to seal unfiled materials, except upon a showing of "good cause." For example, in 1992, a Minnesota trial court denied a motion from a St. Paul City Council member, who was a defendant in a civil lawsuit, to seal all discovery materials on grounds that disclosure would cause her public humiliation and reputational harm. ${ }^{74}$ The court said there was a common law and statutory presumption of openness and, therefore, rejected the closure request as overbroad. ${ }^{75}$

A 2009 case, involving sealed documents filed in twenty-three actions alleging sexual abuse by Roman Catholic clergymen, provides an excellent discussion of the various approaches courts have taken. In Rosado et al. $v$. Bridgeport Roman Catholic Diocesan Corp., the Connecticut Supreme Court ruled that there was a presumptive right of public access to "judicial documents," which it defined as "any document filed that a court reasonably may rely on in support of its adjudicatory function." ${ }^{, 76}$ While the underlying sex abuse cases had been settled and withdrawn in 2001, in 2002 four newspapers filed motions seeking permission to intervene in the cases and requested an order vacating the orders to seal documents. Although the court acknowledged the split regarding the types of judicial documents considered "public," and reviewed the different approaches taken, the court ultimately concluded that because "discovery proceedings can have a significant impact on the eventual resolution of disputes," discovery documents should be public in order to advance the public interest in judicial monitoring. ${ }^{77}$

69. See, e.g., Cipollone v. Liggett Group, Inc., 785 F.2d 1108, 118-20 (3d Cir. 1986) (holding the standard for issuing a discovery protective order is good cause).

70. FED. R. CIV. P. 26. Under Rule 26(c), eight types of protective orders may be issued, but the list is nonexclusive and judges have wide discretion to order other appropriate restrictions. Seattle Times Co. v. Rhinehart, 467 U.S. 20, 36 (1984) ("[T]rial courts are in the best position to weigh fairly the competing needs and interests of parties affect by discovery.").

71. But see also In re Alexander Grant \& Co. Litig., 820 F.2d 352, 356 (11th Cir. 1987) (discussing the operation of umbrella protective orders that postpones the necessary showing of "good cause").

72. See, e.g., In re Reporters Comm. for Freedom of the Press, 773 F.2d 1325 (D.C. Cir. 1985); Tavoulareas v. Washington Post, 724 F.2d 1010 (D.C. Cir. 1984); Booth Newspapers, Inc. v. Midland Circuit Judge, 377 N.W.2d 868 (Mich. Ct. App. 1985); appeal denied, 425 Mich. 854 (1986).

73. See, e.g., West Virginia v. Moore, 902 F. Supp. 715, 717 (S.D. W. Va. 1995) (holding that depositions in a civil recovery for alleged corrupt acts that were never filed with the court were not judicial documents subject to a right of access).

74. Baloga v. Maccabee, No. C3-92-11589, 1992 WL 455440 (Minn. Dist. Ct. Nov. 16, 1992).

75. Id.

76. Rosado et al. v. Bridgeport Roman Catholic Diocesan Corp., 970 A.2d 656, 682 (Conn. 2009), cert. denied, 130 S. Ct. 500 (2009).

77. Id. at 683 
Especially important to the discussion of patent cases is that some courts have denied access to judicial records in order to protect trade secrets. ${ }^{78}$ However, even in these cases, many courts require parties show cause as to why a document should be kept from the public. For example, in 2001 four media companies sued to unseal nine discovery documents and ten pages excerpted from legal briefs from a case brought against Bridgestone/Firestone, Inc., for the death of an 18year-old football player from West Virginia University. The United States Court of Appeals for the Eleventh Circuit used a "good cause" standard to decide whether the sealed discovery documents should be unsealed. ${ }^{79}$ The Eleventh Circuit ruled that under the "good cause" standard, Bridgestone/Firestone's interest in keeping trade secrets confidential had to be balanced against the media organizations' contention that disclosure would serve the public's interest. ${ }^{80}$

A recent high profile patent case provides an excellent example of how judges apply different standards in deciding whether or not to grant a motion to seal court documents. In Apple v. Samsung, ${ }^{81}$ a case involving a $\$ 2.5$ billion patent infringement claim and dubbed "The Patent Trial of the Century," court considered numerous motions to seal documents by both the litigants and a substantial number of third parties. The original motions to seal pertained to several different kinds of documents. Some of the documents were produced by the parties and would be used in the trial. Others were used exclusively for prior motions, such as motions for summary judgment. Finally, third parties created some of the documents that were to be used by either Apple or Samsung at trial. ${ }^{83}$ While neither party opposed the other's motions to seal, Reuters America LLC filed an opposition, something that is common in patent cases. Because the opposing party does not care if the records are sealed so long as they get to see the documents, motions to seal are rarely challenged unless a third party, such as a media organization, intervenes. The district ruled on this motion in August 2012.

Basing its decision on the common law right of access to judicial documents, the court wrote when considering motions to seal, a "strong presumption in favor of access [was] the starting point." ${ }^{84}$ The court then used the good cause standard for "non-dispositive motion[s]" and pre-trial documents and the compelling reason standard for any record "attached to a dispositive motion or presented at trial. ${ }^{" 85}$ However, the court also used the compelling reason standard for pre-trial documents related to the admissibility of evidence, because admissibility of evidence was "such a closely contested issued in [the] trial," and had "become crucial

78. A trade secret "may consist of any formula, pattern, device or compilation of information which is used in one's business, and which gives him an opportunity to obtain an advantage over competitors who do not know or use it." RESTATEMENT (FIRST) OF TORTS $\S 757$, cmt. b (1939).

79. Chicago Tribune Co. v. Bridgestone/Firestone, Inc., 263 F.3d 1304, 1314-15 (11th Cir. 2001).

80. Id.

81. Order Granting-In-Part and Denying-In-Part Motions to Seal at 1, Apple Inc. v. Samsung Electronics Co. et al., No. 11-CV-01846-LHK, 2012 WL 3536800 (N.D. Cal. Aug. 9, 2012).

82. See Ashby Jones \& Jessica E. Vascellaro, Apple v. Samsung: The Patent Trial of the Century, WALL ST. J., July 24, 2012.

83. Apple Inc., 11-CV-01846-LHK, at 1.

84. Id. at 1-2. (citing Kamakana v. City and Cnty. of Honolulu, 447 F.3d 1172, 1178 (9th Cir. 2006)).

85. Id. (citing Pintos v. Pac. Creditors Ass'n, 605 F.3d 665, 678 (9th Cir. 2010)). 
to the public's understanding of the proceedings." 86 The court then weighed each litigants' and third parties' interests in sealing each document against the public's interest in accessing that document. ${ }^{87}$ The public's interest in the document was analyzed in light of the role the document would play in "ensuring the 'public's understanding of the judicial process and of significant public events."

Based on this standard, the district court agreed to seal "only a small number of trial exhibits" and "most exhibits attached to pre-trial and post-trial motions were ordered unsealed." ${ }^{, 89}$ In general, the court sealed information about the parties' production and supply capacities, confidential source code, third-party market research reports, and the pricing terms of licensing agreements. The court unsealed documents disclosing the parties' product-specific profits, profit margins, unit sales, revenues and costs, Apple's proprietary market research, and nonprice terms of licensing agreements. ${ }^{90}$ After trial, Apple moved for a permanent injunction and enhanced damages from Samsung. ${ }^{91}$ In opposing the motion, Samsung submitted exhibits containing information Apple had designated as confidential, in addition to a motion to seal the material. ${ }^{92}$ The district court, however, denied Samsung's motion in November 2012.93

While Apple and Samsung did not challenge most of the district court's orders, both appealed the courts' orders to unseal a "small subset of exhibits attached to pre-trial and post-trial motions." 94 These exhibits had been filed by both parties and contained financial information and market reports. On appeal, the U.S. Court of Appeals for the Federal Circuit based its decision, affirming in part and reversing in part, on the common law right of access to judicial records. The court found that under Ninth Circuit precedent there was "a strong presumption in favor of access to court records." overcome by providing " "sufficiently compelling reasons" that override the public policies favoring disclosure." ${ }^{.96}$ The court wrote the party seeking to seal a judicial record "must articulate compelling reasons supported by specific factual findings that outweigh the general history of access and the public policies favoring disclosure, such as the public interest in understanding the judicial process." also confirmed that under Ninth Circuit precedent, the good cause standard under Federal Rules of Civil Procedure 26(c) was sufficient to seal discovery documents

86. Id. at 7 ("Because admissibility of evidence is such a closely contest issue in this trail, which has become crucial to the public's understanding of the proceedings, the Court will apply the "compelling reasons" standard to documents attached to these non-dispositive motions as well.").

87. Id. at 7-8.

88. Id. at 1-2 (citing Kamakana v. City and Cnty. of Honolulu, 447 F.3d 1172, 1179 (9th Cir. 2006) (quoting Valley Broadcasting Co. v. U.S. Cist. Court for Dist. Of Nev., 798 F.2d 1289, 1294 (9th Cir. 1986))).

89. Apple Inc. v. Samsung Electronics Co. et al., 12-CV-0630-LHK (July 24, 2013).

90. For a complete discussion of the individual documents, see Order Granting-In-Part and DenyingIn-Part Motions to Seal, Apple Inc. v. Samsung Electronics Co. et al., No. 11-CV-01846-LHK, 2012 WL 3536800 (N.D. Cal. Aug. 9, 2012).

91. Order Granting-In-Part and Denying-In-Part Motions to Seal, Apple Inc. v. Samsung Electronics Co. et al., No. 11-CV-01846-LHK at 2 (N.D. Cal. Nov. 29, 2012).

92. Id. at 1.

93. Id.

94. Apple Inc., 12-CV-0630-LHK at 1-2.

95. Id. at 10 .

96. Id.

97. Id. (quoting citing Kamakana v. City and Cnty. of Honolulu, 447 F.3d 1172, 1178-79 (9th Cir. 2006). 
attached to non-dispositive motions. ${ }^{98}$ The Federal Circuit, however, ruled that the district court erred when it applied the compelling reasons standard to documents attached to non-dispositive motions that simply addressed the admissibility of evidence. ${ }^{99}$

Based on these standards, the appeals court overturned the district court's August order to unseal financial documents. The court found the litigants were only seeking to seal a small subset of the documents that they had originally sought to seal, only sought to redact limited portions of that subset, and had a significant interest in preventing the release of their detailed financial information. ${ }^{100}$ The court held that the public had a "minimal interest" in this information. ${ }^{101}$ In addition, the court overturned the district court's November order to unseal nine Apple market research reports. Balancing Apple's interest in sealing the documents with the public's interest, the court ruled that Apple could suffer competitive harm if the reports were made available to the public. In addition, the court noted that Apple agreed to make public all of the information contained in the documents that were actually cited by the parties or the district court. Based on these reasons, the Ninth Circuit held the district court had abused its discretion in ordering all nine market research reports be unsealed. ${ }^{102}$

In Apple v. Samsung, both the district court and appeals court used appropriate standards, despite reaching disparate conclusions. However, it is important to note that not all courts consistently apply the experience and logic test, the presumption of access required by the common law, the "good cause" standard, or any other uniform approach to sealing judicial documents. As Professor Seymour Moskowitz notes, the problem is compounded by the fact that "protective orders are often approved pro-forma by overburdened courts anxious to avoid time consuming . . disputes." 103 Professor Moskowitz also notes that local federal district courts have rules barring or excusing parties from filing discovery materials unless ordered to do so, and local rules often deviate from federal rules in "many particulars." 104 Perhaps because of these inconsistencies, patent trials "often contain mountains of sealed exhibits." 105

\section{STUdying ACCESS TO PATENT LitigATIONS}

In patent cases, there are indications that it is far easier to seal court records than what the law suggests. Reporters and bloggers have written about difficulties accessing important filings in high profile patent cases. ${ }^{106}$ Both courts and the

98. Id. at 11 .

99. Id. at 12 ("[W]e are not aware of any Ninth Circuit precedent applying the 'compelling reasons' standard to non-dispositive motions regarding the admissibility of evidence at trial. The district court's reasoning - that admissibility of evidence was a closely contested issue - does not justify departure from the Ninth Circuit's general rule").

100. Id. at 17.

101. Id. at 19. The court reasoned that disclosure of information in the documents did not promote the public's understanding of the judicial process or significant public events.

102. Id. at 23-24.

103. Moskowitz, supra note 66 , at 826 .

104. Id. at 828 .

105. Apple Inc. v. Samsung Electronics Co. et al., 12-CV-0630-LHK, 3 (July 24, 2013).

106. Evan Hansen, Why Secrecy in Patent Cases Is Out of Control - and What to Do About It (April 30, 2013), https://medium.com/your-digital-rights/112b7784d0a; Dan Levine, Microsoft vs. Google Trial Raises Concerns over Secrecy, REUTERS (Nov. 2, 2012, 2:18 PM), 
press have also complained that parties in patent cases designate almost everything as confidential. ${ }^{107}$ In at least two instances, the courts have chastised parties for attempting to hide basic information like case citations. ${ }^{108}$ One author recounted his frustrations in trying to learn about emerging theories in patent law by looking at district court filings. ${ }^{109}$ Entire briefs in many of the busiest patent courts were frequently sealed. ${ }^{110}$ Unfortunately, it is not clear how pervasive the problem is.

Consequently, the authors are studying the accessibility of patent court records in two contexts. Analyzing transparency from a macro prospective, we are currently conducting the first comprehensive study of judicial transparency in district court patent litigation. More immediately, this Article considers transparency in patent cases by focusing on a single high profile patent case, Monsanto $v$. DuPont. ${ }^{111}$ Together these approaches provide both a quantitative assessment of transparency and a dynamic understanding of what kind of subject matter is hidden from the public when filings are routinely placed under seal.

\section{A. The Transparency Landscape}

Although the subject of this Article is the Monsanto v. DuPont docket, it adopts many of the same metrics the authors are using in their larger, comprehensive study. Consequently, this section provides a brief description of the methodology of the larger study here. All patent cases filed in United States district courts in 2009 are being studied using the Lex Machina database. ${ }^{112}$

In addition to determining the number of filings placed under seal in each case, ${ }^{113}$ the study also counts motions to file under seal and their success rates. ${ }^{114}$ Because some courts require parties to file public versions of any sealed filing, ${ }^{115}$ such redacted versions, and any files that are ultimately unsealed, are also counted. The documents contained in each sealed filing are categorized by subject mat-

http://www.reuters.com/article/2012/11/02/net-us-microsoft-google-secrecyidUSBRE8A106Y20121102.

107. Raymond Baldino, Federal Judge Orders Unsealing of Documents in Ongoing Apple-Samsung Patent Litigation, Reporters Committee for Freedom of the Press (July 20, 2012), available at https://www.rcfp.org/browse-media-law-resources/news/federal-judge-orders-unsealing-documentsongoing-apple-samsung-paten.

108. Apple Inc. v. Samsung Electronics Co. et al, 12-CV-0630-LHK (July 24, 2013) (discussing Google's attempt to seal published case citations filed in support of a motion to quash); In re Violation of Rule 28(d), 635 F.3d 1352 (Fed. Cir. 2011) (issuing sanctions for over designating confidential material).

109. Bernard Chao, Not So Confidential: A Call for Restraint in Sealing Court Records, 2011 PATENTLY-O PAT. L. J. 6 (2011), available at http://patentlyo.com/media/docs/201 1/07/chao.sealed records.pdf.

110. Id. at 7 .

111. No. 09-CV-00686, 2012 WL 2979080 (E.D. Mo. July 20, 2012).

112. The Lex Machina is a database populated by crawling the entire federal court PACER docketing system daily looking for patent documents. See LEX MACHINA, www.lexmachina.com (last visited Apr. 21, 2014).

113. By "filing", we mean a single docket entry in PACER (Public Access to Court Electronic Records). The PACER system allows the public on-line access to federal district court filings.

114. In some districts, most notably the Eastern District of Texas, a party does not have to ask the court to file a document under seal. See LR CV-5(a)(7)(A), E.D. TEX. LOCAL CIV. R., available at http://www.txed.uscourts.gov/page1.shtml?location=rules:local.

115. See Civil Standing Order Regarding Motions To File Under Seal U.S. District Judge Lucy H. Koh (December 1, 2011), available at http://www.cand.uscourts.gov/lhkorders. 
ter. The three subject matter categories are: summary judgment, discovery, and other. In some cases, courts even seal their own rulings. Consequently, the study also counts these occurrences.

\section{B. Monsanto v. DuPont}

The Monsanto v. DuPont case was chosen for this case study for a number of reasons. First, it was a high profile patent case of significant public importance. Monsanto developed and patented a strain of genetically modified soybean plant that is resistant to Monsanto's Roundup herbicide. The resulting seeds were so successful that by 2011 Monsanto controlled approximately $90 \%$ of the soybean seed market. ${ }^{116}$ DuPont sought to develop its own Roundup resistant seed and obtained a license from Monsanto to do so. However, the scope of that license was disputed, and Monsanto sued DuPont for patent infringement. Monsanto eventually prevailed at trial, receiving a jury verdict of one billion dollars, one of the largest awards in a patent infringement case in U.S. history. ${ }^{117}$

Second, Monsanto v. DuPont involved a new, untested patent damages theory. Traditionally, damages in patent cases are awarded based on sales of infringing product. However, in the Monsanto case, the one billion dollar award was based on seeds DuPont had developed, but not yet sold. Thus, the precise contours of this damages theory are of interest to practicing attorneys, judges, and academics alike. $^{118}$

Finally, the Monsanto case went to trial, and many of its filings are under seal. Thus, it illustrates the different categories of subject matter that are sealed and the different procedures utilized to keep information from the public. To be clear, the Monsanto case is not representative of patent litigation generally. Rather, it represents one end of the spectrum. To provide some context, at the time that this Article was being edited, 601 cases with 50 or more docket entries had been coded in the study. Only one of those cases contains a higher percentage of sealed documents. ${ }^{119}$

\section{The Numbers}

Before delving into the details of Monsanto $v$. DuPont, this section assesses the case using methods described above. Monsanto filed its complaint on May 4, 2009 , in the Eastern District of Missouri. The jury returned its verdict on August 1, 2012. The case settled in March of 2013, but filings continued through June 18, 2013.

116. AP: Monsanto Strong-Arms Seed Industry, CBSNEWS (Dec. 14, 2009, 1:20 PM), http:/Www.cbsnews.com/2100-500395_162-5978152.html?pageNum=1.

117. Joe Whittington, Andrew Harris \& Jack Kaskey, Monsanto Awarded \$1 Billion Against DuPont by Jury, BLOOMBERG (August 2, 2012, 8:59 AM), http://www.bloomberg.com/news/2012-0801/monsanto-awarded-1-billion-against-dupont-by-jury.html.

118. For a more in depth analysis of Monsanto's damages theory, see Bernard Chao \& Jonathan R. Gray, A $\$ 1$ Billion Parable, 90 DENV. U. L. REV. OnLINE 185 (2013).

119. Since the study has not finished our quality controls, we will not release the name of that case yet. 
There were a total of 1,697 docket entries in this case. ${ }^{120}$ Five hundred ninetyone PACER entries were filed under seal, $34.9 \%$ of all the entries in the case. The parties filed seventy motions to seal, all of which the court granted. Additionally, on February 15, 2011, the court issued an order sua sponte allowing the parties to submit filings under seal "without leave of Court." the parties no longer had to seek leave from the court to seal their filings. ${ }^{122}$

The sealed filings broke down as follows: 183 related to summary judgment motions, ${ }^{123} 140$ motions related to discovery, and 271 "other" motions. The court even sealed 34 of its own rulings. Prior to the February 15, 2011 sua sponte order, the parties filed public redacted copies of all sealed documents. However, despite the fact that the February 15, 2011 order did not expressly relieve the parties of the responsibility to file redacted copies of sealed documents, the parties stopped filing public versions after the order was issued. Consequently, only 65 of the 592 sealed filings were filed with corresponding public redacted versions. The remaining 527 filings were completely hidden from the public eye. The Court did eventually attempt to unseal six filings, all of them court orders. Nevertheless, two "unsealed" orders remain inaccessible through PACER ${ }^{124}$ A summary of these findings is found in Table A, below.

\section{Table A}

Monsanto v. DuPont, Transparency Metrics ${ }^{125}$

\begin{tabular}{|l|r|}
\hline Pacer Entries & 1,697 \\
\hline Filings Under Seal $^{126}$ & 592 \\
\hline Related to Summary Judgment & 183 \\
\hline Related to Discovery & 140 \\
\hline Related to Other & 271 \\
\hline
\end{tabular}

120. A complete listing of the PACER docket sheet is available at one of the author's website. See Faculty Profile, UNIVERSITY OF DENVER STURM COLLEGE OF LAW, http:/www.law.du.edu/index.php/profile/bernard-chao. The docket is available under a pull down menu labeled "Information on Empirical Research."

121. Order relating to Under Seal Pleadings (Feb. 15, 2011), Monsanto Co. v. E.I. Dupont DeNemours \& Co., No. 09-CV-00686, 2012 WL 2979080 (E.D. Mo. July 20, 2012) [hereinafter Monsanto v. DuPont].

122. After February 17, 2011, the one exception occurred on August 16, 2012 when DuPont filed a Notice Of Intent To Request Redaction. This request related to portions of the August 1, 2012 trial transcript. See infra notes 152-154 and accompanying text. The only reason given for the request is that the relevant passages relate to a sidebar out of hearing of the jury and the public.

123. As discussed later, that is the large majority of filings that were related to the parties' summary judgment motions.

124. An order unsealing four previously sealed court orders was issued on Nov. 16, 2011. The orders that still remain sealed are an order granting a motion for sanctions dated Dec. 21, 2011 and an order that appeared to address motions in limine and Daubert motions, dated Jun. 29, 2012.

125. All fields are assessed by counting the number of PACER entries that fall under each category. Thus, a summary judgment motion with exhibits is counted as one filing so long as there is only a single PACER entry.

126. Two filings were categorized as related to both summary judgment and discovery. They were a brief and declaration that were filed in opposition to a Monsanto motion for partial summary judgment and in support of DuPont's own motion for continuance and discovery. Monsanto v. DuPont (Dec. 17, 2009). 


\begin{tabular}{|l|r|}
\hline Motion/Application to File Under Seal & 70 \\
\hline Granted & 70 \\
\hline Denied & 0 \\
\hline Public Redacted Version Available & 65 \\
\hline Subsequently Unsealed & 6 \\
\hline
\end{tabular}

\section{Light (or No) Judicial Review}

This Article looks beyond the numbers and analyzes what kind of material is being placed under seal. Presumably, studying motions to seal would shed light on the general nature of the hidden information, as parties must justify their requests under either the compelling interest or the good cause standards. However, even when the Monsanto parties did seek the court's permission to seal filings, the motions were strikingly unhelpful. For the most part, the motions simply characterize information as "confidential" without providing any meaningful detail. ${ }^{127}$ Unsurprisingly, the various orders granting motions to seal are terse and uninformative docket entries. ${ }^{128}$ The orders contain no descriptions of the confidential materials, or anything to suggest that the court made independent determinations that the confidentiality claims were justified. Thus, the motions to seal, and the corresponding orders, suggest that even when the court was reviewing requests to seal, it did not subject the parties' motions to the standards discussed above. Rather, the court appears to have taken the parties at their word and allowed them to file any document that they desired under seal. This conclusion is corroborated by the court's failure to deny even one motion to seal. Additionally, the fact that the court instructed the parties to submit filings under seal without judicial approval also suggests that the court was either uninterested in considering the merits of such motions, or too busy to do so.

The court's failure to scrutinize motions to seal presents another, perhaps unforeseen, problem for judicial transparency. It was often difficult to determine even the general nature of some of the Monsanto filings. Instead of analyzing the motions to seal, or corresponding orders, the two primary methods available to determine which information was sealed were to examine the portions of the redacted filings that were left intact or to review the docket entries available on PACER. The entries often provided an informal title of the filing. In some cases, even these entries were unavailable. The only evidence that such documents existed was that certain file numbers appeared to be skipped on PACER. Often a later filing referred to a missing file number and provided its title. Due to these difficulties, this essay describes some documents that the authors were unable to read. ${ }^{129}$

127. See, e.g., Defendants' Motion for Leave to File Answer and Counterclaims and Memorandum in Support of Defendants' Motion to Dismiss Under Seal, Monsanto v. DuPont (June. 16, 2009) (simply noting that the filings contained "confidential and proprietary information."); DuPont \& Pioneer's Request for Redaction of Transcript of October 12, 2010 Hearing, Monsanto v. DuPont (Nov. 10, 2010) (saying that the identified portions of the transcript is "consistent with the Court's Order dated October 15, 2010." Unfortunately, the October 15 order was also filed under seal and there is no indication in the docket entry of what subject matter it addresses.).

128. One example is the May 20, 2009 entry which says, "Docket Text ORDER: Motion to Seal Documents [doc. \#3] is GRANTED. The Unredacted Complaint and Exhibits B and C shall remain sealed by this Court." See supra note 120 .

129. Where such descriptions are provided, the reasons underlying the analysis are explained. 


\section{Redacted Pleadings}

The very first motion to seal filed in the Monsanto case clearly illustrates some of the difficulties in learning precisely what was sealed and why. Monsanto successfully moved to file portions of its Complaint under seal. Monsanto's request was short and conclusory, stating:

Both the Complaint and the License Agreements contain confidential and proprietary information, as defined in the License Agreements. Therefore, it is necessary to seal Exhibits B and C in their entirety, as well as those portions of the Complaint that provide specific terms contained in the License Agreements. ${ }^{130}$

Although this motion reveals Monsanto's attempt to keep some terms of their licenses secret, it does not provide any description of those terms, explain why they are confidential, or suggest any specific harm that would result from disclosure. Unless the court actually compared the sealed version of the Complaint with the redacted version, it could not have identified the confidential material, let alone, assessed the merits of Monsanto's confidentiality claims. There is also no way to determine if the court performed this analysis because the motion was granted with no comment. ${ }^{131}$

An examination of the public version of the Complaint reveals that Monsanto redacted more than just a few licensing terms. ${ }^{132}$ Although unredacted parts of the Complaint identify the parties, the general subject matter, ${ }^{133}$ and the general legal theories, ${ }^{134}$ there is no way for the public to ascertain what the wrong DuPont is alleged to have committed. Large portions of the Complaint are completely blacked out and the surrounding paragraphs do not provide sufficient context to determine what is missing. ${ }^{135}$ Even passages describing the injunction that Monsanto sought are redacted. . $^{136}$

Examining the different causes of action illustrates the difficulty of comprehending the Complaint. For example, Count I, entitled "Patent Infringement ('247 Patent')," "37 alleges infringement of "one or more claims of the '247 Patent' by , ${ }^{138}$ The redaction continues for two lines. Similarly, Count II alleges that the defendants induced others to infringe the ' 247 patent,' but four paragraphs of the Count are redacted. ${ }^{139}$ Two of these paragraphs were unsealed in a later court ruling, revealing that Monsanto had sought to hide information that

130. Motion for Leave to File Un-redacted Complaint and Certain Exhibits Under Seal at 2, Monsanto v. DuPont (May 4, 2009); see supra note 120.

131. See supra note 128 for the text of the order.

132. Complaint, Monsanto v. DuPont (May 4 2009). Again, the authors have made this document available. See supra notes 113, 120 at http:/www.law.du.edu/documents/directory/full-time/chaodockets/Monsantos-Complaint-Redacted.pdf [hereinafter Complaint].

133. Id. at 1-3. The dispute concerns soybean and corn seeds that have been genetically modified to be resistant to Roundup. Id. at 3.

134. Id. These theories are patent infringement, breach of contract and unjust enrichment. Id. at 1 .

135. For example, paragraphs $16-29$ and $31-44$ of the Complaint are completely redacted while paragraph 30 is partially redacted. Id. at $6-11$.

136. Id. at $22-25$.

137. The ' 247 patent' is United States Patent No. RE 39,247E. Id. at 3.

138. Complaint, supra note 132, at 14-15.

139. Id. at $15-16$. 
was not proprietary, and which was already available to the public. ${ }^{140}$ It is unclear why Monsanto redacted these statements considering that it had previously issued a press release announcing the lawsuit, and stating that it was suing DuPont to prevent it from using Roundup Ready technology in crops that already had the Optimum GAT trait. ${ }^{141}$ Thus, it appears from the court filings that Monsanto redacted information already widely available to the public without any intervention or oversight from the court.

Monsanto also heavily redacted the breach of contract claims. Count VI alleges that the defendants breached two separate agreements, the so-called "Soybean License Agreement" and "Soybean Trademark License Agreement." However, there is no way for the public to determine what contract terms were at issue or what activity constituted the alleged breach. The count contains eight paragraphs. ${ }^{142}$ Five paragraphs are completely redacted and two others are partially redacted. One of the partially redacted paragraphs incorporates by reference other portions of the complaint, which are also mostly redacted. The other partially redacted paragraph alleges that Monsanto suffered some unspecified damage as a result of the defendants' breach. It is unclear how public disclosure of the scope of the license grant would harm either party. Additionally, studying this dispute might have helped attorneys to draft less ambiguous license agreements in the future. If the court had engaged in any sort of balancing test, it is clear that the court would have favored transparency in the public interest, as no reason for sealing the documents is stated or discernable.

In an apparent about face, Monsanto subsequently filed a motion for judgment on the pleadings that divulged some of the very information that appears to have been redacted from the original Complaint. ${ }^{143}$ Although the specific contract language remained redacted, the subsequent motion provides a much fuller description of the parties' dispute. It reveals that Monsanto had previously granted DuPont a license to its Roundup resistant technology, but that Monsanto did not interpret the license as allowing DuPont to combine this technology with DuPont's own Roundup resistant technology, Optimum ${ }^{\circledR}$ GAT ${ }^{\circledR} .{ }^{144}$ DuPont disagreed with this interpretation and had publically announced that it was planning to sell seeds with both of these traits. The result was a lawsuit. Because DuPont was using Monsanto's patented technology in a manner that Monsanto believed was not permitted by the license, it brought both patent infringement and breach of contract claims against DuPont.

140. One of the two paragraphs that were later revealed was Paragraph 72, which alleges: 72. Upon information and belief, [Pioneer's] statement to . . third-party licensees that the licensees can permissibly stack Monsanto's patented 40-3-2 Soybean Event with the Optimum( GAT $®$ gene is inducing these licensees to directly infringe the '247 Patent.'

See Plaintiffs' Memorandum in Support of Their Motion for Partial Judgment on the Pleadings, Monsanto v. DuPont (July 22, 2009); Monsanto Challenges Unauthorized Use of Roundup Ready® Technology by DuPont (May 5, 2009), available at http://news.monsanto.com/press-release/monsantochallenges-unauthorized-use-roundup-ready-technology-dupont.

141. See Monsanto Challenges Unauthorized Use, supra note 140.

142. Complaint, supra note 132 , at 15-16.

143. See Plaintiffs' Memorandum in Support of Their Motion for Partial Judgment on the Pleadings, Monsanto v. DuPont (Jul. 22, 2009).

144. Id. at 2. ("At issue in this litigation is whether Defendants have the right under these License Agreements to combine or 'stack' their glyphosate-tolerant Optimum® GAT® technology with Monsanto's glyphosate-tolerant Roundup Ready $(\mathbb{R})$ soybean or corn technology. Under the clear and unambiguous terms of the License Agreements, the answer is no."). 
Comparing Monsanto's motion for a judgment on the pleadings with its original Complaint reveals that Monsanto's characterization of what constituted "confidential" information was inconsistent. For example, the redacted version of Monsanto's motion for judgment on the pleadings characterizes Count III of the Complaint as pleading "breach of contract based on Defendants' unlawful stacking of Monsanto's 40-3-2 with Defendants' Optimum ${ }^{\circledR}$ GAT ${ }^{\circledR}$," and Count VIII as pleading a breach of contract based on "Defendant's unlawful stack of Monsanto's NK603 with Defendant's Optimum $B$ GATß."145 Although the public version of the Complaint identifies the specific licenses that were the subject of each Count's breach of contract claim, references to Monsanto's 40-3-2 technology, Monsanto's NK60 technology, and Optimum ${ }^{\circledR}$ GAT ${ }^{\mathbb{B}}$ are missing, presumably redacted. ${ }^{146}$

This inconsistency suggests that at least some of the information Monsanto redacted from its Complaint was not truly confidential. Indeed, the court's opinion granting Monsanto's motion was not redacted at all and quoted the key sections of the license agreements. ${ }^{147}$ The opinion also quoted directly from redacted portions of Monsanto's Complaint. ${ }^{148}$ Moreover, immediately after the Court granted the motion, Monsanto issued a press release touting the ruling. ${ }^{149}$ This press release disclosed some of the same specific subject matter that Monsanto had previously redacted from its Complaint.

\section{Secret Summary Judgment Proceedings}

As the Monsanto case progressed, even more of the case was hidden from public view. Summary judgment motions are usually a crucial stage of any patent litigation. The parties typically disclose a detailed theory of their case or risk losing claims or defenses. Consequently, observers should be able to determine the key facts and legal theories of a case by reading the briefs filed in connection with the parties' summary judgment motions.

In the Monsanto case, seventeen separate summary judgment motions were filed, eight by the plaintiff and nine by the defendant. These motions are listed in Appendix A, in chronological order. Each motion is referred to by its corresponding number in the appendix. Sixteen of the seventeen memoranda filed in support of the parties' motions were sealed. Only one memorandum was entirely accessible by the public (SJ 2). Of the sixteen sealed briefs, there is only one public redacted filing (in connection with SJ 1). ${ }^{150}$ The responses and replies followed the same pattern. Of the 15 sets of responses and replies filed in opposition to these

\footnotetext{
145. Id. at 13

146. Complaint at 16-17, 21, Monsanto v. DuPont (May 4, 2009).

147. Monsanto v. DuPont at 6-8, 14 (Jan. 15, 2010) (quoting from six different sections of the Monsanto DuPont license).

148. Id. at 12-13.

149. Federal Court Finds DuPont is Not Licensed to Use Monsanto's Roundup Ready® Trait in Combination With the DuPont Optimum( $\left(\mathbb{R}^{2}\right.$ GAT $(\mathbb{R})$ Trait (Jan. 19, 2010), $\mathrm{http} / /$ news.monsanto.com/press-release/federal-court-finds-dupont-not-licensed-use-monsantosroundup-ready-trait-combination-. "The Court ruled that the Monsanto-DuPont license agreements 'are unambiguous and do not grant Pioneer the right to stack' the Roundup Ready trait with the Optimum GAT trait.")

150. In other words, 15 of the 17 opening briefs, or $88 \%$, were filed completely under seal. See infra app. A.
} 
motions, ${ }^{151}$ only one set of briefs was filed without any restrictions (again SJ 2). One set of briefs was redacted (again SJ 1). ${ }^{152}$ The remaining thirteen sets, representing $87 \%$ of the briefs filed, were filed completely under seal.

More surprisingly, the court rulings were also sealed. The court appears to have issued twelve opinions (SJs 5, 7-17). ${ }^{153}$ The term "appears" is used because all twelve rulings were originally sealed with no redacted public counterparts. However, the docket entries for each of these orders mention a "Sealed Memorandum and Order," suggesting that the court issued written opinions explaining the reasoning for its decisions. It is clear that this was the case for at least two of the court's decisions. After the trial, the court granted Monsanto's motion to unseal the rulings on SJS 11 and $12 .{ }^{154}$ Thus, these two formerly secret orders are now available. Oddly, the briefings underlying SJs 11 and 12 remain sealed.

Although some of these summary judgment motions undoubtedly touch on confidential subject matter, many of the motions do not appear to concern anything secret. For example, the titles of SJs 8 and 16 indicate that they involve 35 U.S.C. $\S 112$ 's enablement and written description requirements. The enablement requirement is satisfied when a person of ordinary skill in the art, after reading the specification, could practice the claimed invention without undue experimentation. ${ }^{155}$ The written description requirement is satisfied when the specifications "allow persons of ordinary skill in the art to recognize that the inventor invented what is claimed." 156 If either requirement is not satisfied, the corresponding patent claim is invalid. Importantly, the inquiry underlying both defenses is simply whether the patent specification contains sufficient technical detail to justify the claim. Thus, these two defenses involve an analysis of a public document, namely the patent at issue. There is no reason why briefs addressing these issues would delve into the parties' secrets. Moreover, since both requirements are assessed based on knowledge available at the time the patent was first filed, ${ }^{157}$ information after the filing date of the patent is not particularly relevant. Thus, even if briefing in this case touched upon some confidential technical documents, that information was probably at least 20 years old. ${ }^{158}$ In sum, SJs 8 and 16 appear to concern ar-

151. In two cases (SJ 3 and SJ 4), no responses were filed. The Court denied the motions with leave to refile the motions at the close of discovery. See infra app. A., DE\# 550.

152. The PACER entry does not mention that the reply brief was redacted, but a review of the document reveals the redactions. Monsanto v. DuPont (Jan. 19, 2010).

153. The Court issued a docket order denying SJs 1-4 with permission to refile them at a later date. Monsanto v. DuPont (Aug. 29, 2011). A different docket order dated June 5, 2012.

154. Monsanto v. DuPont (Nov. 16, 2012). Ironically, the briefing on the motion to unseal remains completely under seal. See Plaintiffs' Memorandum in Support of Their Motion to Unseal Orders Rejecting Defendants Claims That They Had Rights To Stack and Access Monsanto's Regulatory Data (Aug. 24, 2012); Memorandum in Opposition to Motion to Unseal (Oct. 5 2012); Plaintiffs' Reply Memorandum in Support of Their Motion to Unseal Orders Rejecting Defendants' Claims that they had Rights to Stack and Access Monsanto's Regulatory Data (Oct. 15, 2012).

155. Hybritech, Inc. v. Monoclonal Antibodies, Inc., 802 F.2d 1367, 1384 (Fed. Cir. 1986).

156. Ariad Pharm., Inc. v. Eli Lilly \& Co., 598 F.3d 1336, 1351 (Fed. Cir. 2010) (en banc).

157. In re Wands, 858 F.2d 731, 735-37 (Fed. Cir. 1988) (discussing the enablement requirement); Vas-Cath Inc. v. Mahurkar, 935 F.2d 1555, 1563-64 (Fed. Cir. 1991) (discussing the written description requirement).

158. The filing date of the patent at issue, RE 39,247, was September 13, 1994. See USPTO Patent Full-Text and Image Database, http:/patft.uspto.gov/netacgi/nphParser?Sect $1=$ PTO $1 \&$ Sect $2=$ HITOFF $\& d=$ PALL\&p $=1 \& u=\% 2$ Fnetahtml $\% 2 F P T O \% 2$ Fsrchnum.htm\&r=1\&f=G\&l=50\&s1=RE39247.PN.\&OS=PN/RE39247\&RS=PN/RE39247. 
guments regarding publicly available information, yet no version of either the briefs or the court's decisions were made available to the public.

Other summary judgment motions also appear to focus on issues of public concern. For example, SJ 14 involves another $\S 112$ requirement, that a patent contain definite claims. Because the claims are intended to give the public notice of the scope of the inventor's patent, a claim that is "insolubly ambiguous" is invalid as indefinite. ${ }^{159}$ Again, the underlying inquiry is an assessment of publicly available material; a reading of the patent's claims in view of the specification. And once again, both the briefing and ultimate ruling are unavailable.

SJ 15 concerns the defendants' allegations of inequitable conduct. If proven, this defense bars enforcement of a patent. Typically, inequitable conduct occurs when the inventors or their representatives intentionally withhold prior art or make false statements during the prosecution of a patent. ${ }^{160}$ Thus, an inquiry into potential inequitable conduct delves into the patentee's behavior during the prosecution of the patent. Although disclosure of such information is potentially embarrassing, it does not involve trade secrets. Presumably, no court would allow allegations of fraud against Enron to be sealed simply because they might shame its corporate officers. Neither should a court allow allegations of misconduct against Monsanto to be placed under seal. ${ }^{161}$ But again, the SJ 15 briefing and ruling are completely sealed.

In other instances, the summary judgment motion may have involved confidential subject matter, but it is likely that such motions also addressed issues of public interest. For example, SJs 4, 9 and 15 concern issues of infringement. Infringement is determined by comparing the accused technology to the patent's claims. Thus, these motions likely contain both technical details about the accused DuPont seeds, and interpretations of Monsanto's patent claims. Although DuPont may have had a legitimate interest in sealing some of the technical details regarding its genetically modified seeds, the public has a strong interest in learning about the precise boundaries of Monsanto's patent. ${ }^{162}$ The solution is simple: redact descriptions of DuPont's secrets and leave the remainder of the filings intact. ${ }^{163}$

The parties' own positions reveal another reason to question the "confidentiality" of some of the motions. Soon after the trial ended, Monsanto moved to unseal various filings, including the court's rulings on SJs 11 and $12 .{ }^{164}$ Although the briefing on this motion is under seal, the Court's ruling was public and it characterizes the parties' positions. ${ }^{165}$ Monsanto argued:

159. Star Scientific, Inc. v. R.J. Reynolds Tobacco Co., 537 F.3d 1357, 1371 (Fed. Cir. 2008).

160. Therasense, Inc. v. Becton, Dickinson and Co. 649 F.3d 1276, 1291-92 (Fed. Cir. 2011) (en banc).

161. See, e.g., Glenmede Trust Co. v. Thompson, 56 F.3d 476, 484 (3d Cir. 1995) (holding that embarrassment that may result from the distribution of judicial documents is insufficient under the good cause standard to warrant the sealing of documents).

162. See supra Part I(B).

163. See Bernard Chao, Not So Confidential: A Call for Restraint in Sealing Court Records, 2011 PATENTLY-O PAT. L.J. 6, 10-11 (2011), available at http://patentlyo.com/media/docs $/ 2011 / 07 /$ chao.sealedrecords.pdf (arguing that parties should be forced to file public versions of any documents they file under seal).

164. Monsanto v. DuPont at *2 (Nov. 16, 2012) (under seal)

165. Monsanto v. DuPont at*1 (Aug. 24, 2012). 
$[\mathrm{T}]$ here is no compelling reason to shield from the public this Court's decision relating to its determination of Monsanto's breach-of-contract claims, its declaration of the parties' rights under the seed license agreements, its rejection of Defendants' position that it should be entitled to access Monsanto's technology under the Hatch-Waxman Act, or its finding that Defendants committed fraud upon this Court in an effort to manipulate the judicial process for their own business interests. ${ }^{166}$

Moreover, the "Defendants agree[d] that there [was] no reason to maintain under seal the two June 6, 2012 orders..." ${ }^{167}$ Consequently, the court unsealed the rulings on SJs 11 and 12 . These comments beg the question: Why were the briefs filed completely under seal when the parties were apparently unconcerned about disclosing the court's entire ruling? What is more, why do the briefs remain under seal when the decisions are now public? Do the briefs contain some confidential material that the decisions do not, or did everyone just overlook the sealed briefs?

\section{Trial}

After Monsanto v. DuPont, there is both good news and bad news for the future of open access. First, the bad news: Immediately, before the Monsanto trial began, the parties filed their motions in limine, proposed jury instructions, exhibit lists, and corresponding objections. Most, if not all, of these documents were filed under seal. As previously discussed, by this point in the case the parties were no longer seeking court permission to seal. Thus, there is no explanation for why some of the most basic trial documents are sealed. This section analyzes the motions in limine filed, which are representative of the larger set of filings.

All together the parties appear to have filed twenty-eight motions in limine. However, there are no docket entries for twenty-six of these motions. The only indications of their existence are corresponding responsive briefs. The docket entries for the responses reference missing docket entries that should be associated with the original motions in limine. ${ }^{168}$ Additionally, both the transcripts of the hearings on these motions, ${ }^{169}$ and the court's rulings, ${ }^{170}$ are unavailable. It is clear that at least some of these motions should not have been filed under seal. For example, it is difficult to imagine why a secret proceeding is required to determine the sequence of a patent trial. ${ }^{171}$

166. Id. at *3.

167. Id.

168. For example, the docket skips entries 1353-54, 1356, 1358-1372. Although most of these numbers correspond with the missing motions in limine, for some docket entries there is no publicly available information, making it impossible to determine the nature of the missing filings. Appendix B lists all the motions in limine that the authors were able to identify and indicates whether the briefs were sealed or entirely missing from the docket. See infra app. B.

169. The docket entries of June 26 and 27, 2012 indicate that there was pretrial conferences concerning Daubert motions and motions in limine on those days. The entries also say that the Court ordered that the proceeding be "sealed and that any transcript prepared from this proceeding be filed under seal." See supra note 124; see also infra app. B.

170. Monsanto v. DuPont (Jun. 29, 2012). See supra note 124; see also infra app. B.

171. See infra app. B, DE\# 1363.. Another example is Defendants' Motion in Limine No. 4 for Clarification that Inequitable Conduct is to be tried before a Jury. See infra app. B. Arguments about whether a particular defense is to be heard by the judge or jury are extremely unlikely to contain information that will be harmful if disclosed. 
Finally, there was a small bit of good news. The Monsanto trial transcripts appear to be largely intact. There were eighteen days of jury trial transcripts designated as Volumes I thru XVIII. All the transcripts were made publicly available except for two. ${ }^{172}$ For the proceedings on the morning of July $27,{ }^{173}$ and the entire day of August $1,{ }^{174}$ there are docket entries reflecting both a redacted transcript and a transcript that was filed completely under seal. Three different relatively short portions of the July 27 transcript are redacted. ${ }^{175}$ Three different portions of the August 1 transcript are similarly redacted. ${ }^{176}$ Although each redaction is prefaced with a statement providing that the redacted material related to sealed portions of the transcript "by Order of the Court," no such order, nor any filings explaining the bases for these redactions, could be found. Thus, while most of the trial appears open to the public, it is impossible to determine if the court applied the correct legal standards when it sealed testimony.

In sum, this article analyzed three phases of the Monsanto case, the pleadings, motions summary judgment, and trial, in order to demonstrate that the large majority of the case was hidden from the public eye. Not until the trial commenced, did the Court begin to provide the public some level of access to this case. Even so, the parties' court filings still remain hidden from the public to this very day. ${ }^{177}$ Consequently, companies that would like to make their own genetically modified seeds cannot study the court records to assess whether Monsanto's patent is likely to be valid, let alone, learn more precisely what it covers.

\section{CONCLUSION}

This article analyzes the Monsanto v. DuPont case in order to highlight the pervasive lack of transparency in patent litigation. Although sealing $34.9 \%$ of the docket is hardly representative, this case is still quite informative. This case demonstrates the need for procedural safeguards to protect the public's right to know the contents of patent suit dockets, and for courts to take such safeguards seriously. Otherwise, when litigants are given an essentially unfettered ability to seal their filings, they seal far too much. Some of the most basic pleadings and important motions in the Monsanto case were hidden. The habit of sealing documents even crept into the court's practice as numerous rulings were sealed in their entirety. Admittedly, the authors have not offered a comprehensive solution in this article. Nonetheless, our hope is that greater awareness of the transparency prob-

172. This assessment was made by examining the title of the docket entry. If the docket entry said that the transcript was under seal or redacted, it was categorized accordingly. In addition, each public unredacted transcript was downloaded. An automated search for the terms "redact" and "seal" was conducted to verify that there were no "redacted" portions. For more on these docket entries, see Monsanto Company et al v. E.I. Dupont De Nemours and Company et al, http://www.plainsite.org/dockets/index.html?id=1883924 (last visited Mar. 12, 2014).

173. Id. at DE \#\# $1574,1575$.

174. Id. at $\mathrm{DE} \#$ \# $1581,1582$.

175. Transcript of Trial - Volume XV-A at 96, 98, 126, 127, Monsanto v. DuPont (August 16, 2012); see also supra note 120 , at 175 .

176. Transcript of Trial - Volume XVIII at 115, 117, 245, 246, 248, Monsanto v. DuPont (August 1, 2012). See also supra note 120 , at 177-78.

177. For example, the following motions were all filed under seal on August 16, 2012: 1) Motion for Judgment as a Matter of Law and/or a New Trial, 2) Plaintiffs' Motion for Finding of Objective Willful Infringement and Enhanced Damages, 3) Motion to Vacate Damages Award or, in the Alternative, for Remittitur or a New Trial on Damages. See supra note 120, at 179-80. 
lem will lead to a robust conversation and eventually cause courts to take their duty to safeguard the public's rights to access judicial records more seriously. 


\section{APPENDIX A}

\section{Summary Judgment Motions}

$\mathrm{R}=$ Filed Under Seal with Redacted Public Version Available

$\mathrm{S}=$ Filed Completely Under Sealed

Numbers refer to docket entry numbers in the PACER docket.

\begin{tabular}{|c|c|c|}
\hline $\begin{array}{l}\text { \#. Title of Summary } \\
\text { Judgment Motion }\end{array}$ & $\begin{array}{l}\text { Motion, } \\
\text { Memorandum }^{178} \\
\text { Response, Reply }\end{array}$ & Court Ruling \\
\hline $\begin{array}{l}\text { 1. Monsanto's Motion for Partial Summary } \\
\text { Judgment of Infringement of Claims } 116,119 \text {, } \\
122 \text { and } 125 \text { of the ' } 247 \text { RE Patent" by Plain- } \\
\text { tiffs Monsanto Technology LLC, Monsanto } \\
\text { Company }\end{array}$ & $\begin{array}{l}94, \\
95 \mathrm{R} \\
118 \mathrm{R} \\
137 \mathrm{R}^{179}\end{array}$ & $\begin{array}{l}550 \text { DENIED } \\
\text { with leave to } \\
\text { refile }\end{array}$ \\
\hline $\begin{array}{l}\text { 2. Defendants' Motion for Partial Summary } \\
\text { Judgment of Invalidity for Improperly Broad- } \\
\text { ened Reissue Claims }\end{array}$ & $\begin{array}{l}215 \\
216 \\
280 \\
306\end{array}$ & $\begin{array}{l}550 \text { DENIED } \\
\text { with leave to } \\
\text { refile }\end{array}$ \\
\hline $\begin{array}{l}\text { 3. Defendants' Motion for Partial Summary } \\
\text { Judgment of Anticipation of the Asserted Plant } \\
\text { Genus Claims of the ' } 247 \text { RE Patent Over PCT } \\
\text { Application No. WO } 92 / 0449 \text { Based on Acqui- } \\
\text { escence }\end{array}$ & $\begin{array}{l}599 \mathrm{~S}, \\
601 \mathrm{~S}, \\
\text { None, } \\
\text { None }\end{array}$ & $\begin{array}{l}849 \text { DENIED } \\
\text { with permission } \\
\text { to refile }\end{array}$ \\
\hline $\begin{array}{l}\text { 4. Defendants' Motion for Partial Summary } \\
\text { Judgment of Absolute } \\
\text { Intervening Rights by Defendants E.I. } \\
\text { Dupont De Nemours and Company }\end{array}$ & $\begin{array}{l}610 \mathrm{~S}, \\
611 \mathrm{~S}, \\
\text { None, } \\
\text { None }\end{array}$ & $\begin{array}{l}849 \text { DENIED } \\
\text { with permission } \\
\text { to refile }\end{array}$ \\
\hline $\begin{array}{l}\text { 5. Plaintiff's MOTION for Partial Summary } \\
\text { Judgment of Count Nine for Invalidity of the } \\
\text { '247 Patent Claims Reciting Seq ID No: } 70\end{array}$ & $\begin{array}{l}1068 \\
1069 \mathrm{~S} \\
1160 \mathrm{~S} \\
1278 \mathrm{~S}\end{array}$ & $\begin{array}{l}1383 \mathrm{~S} \text { MSJ } \\
\text { DENIED }\end{array}$ \\
\hline $\begin{array}{l}\text { 6. Defendants' MOTION for Partial Summary } \\
\text { Judgment of Claims Regarding Corn Products } \\
\text { (Counts I, VIII and IX and Counterclaim } \\
\text { Counts Eight and Eleven) }\end{array}$ & $\begin{array}{l}1085, \\
1086 \mathrm{~S}, \\
1169 \mathrm{~S}, \\
1290 \mathrm{~S}\end{array}$ & $\begin{array}{l}1307 \text { DENIED } \\
\text { AS MOOT }\end{array}$ \\
\hline $\begin{array}{l}\text { 7. Defendants' MOTION for Partial Summary } \\
\text { Judgment Declaring That The Earliest Effec- } \\
\text { tive Filing Date For The Plant Genus Claims } \\
\text { Of The '247 Re Patent Is September 13, } 1994 \\
\text { Based On Acquiescence }\end{array}$ & $\begin{array}{l}1091, \\
1092 \mathrm{~S}, \\
1191 \mathrm{~S}, \\
1285 \mathrm{~S}\end{array}$ & $\begin{array}{l}1394 \mathrm{~S} \text { MSJ } \\
\text { DENIED }\end{array}$ \\
\hline
\end{tabular}

178. The parties filed motions for summary judgment that simply provide a short description of each motion separately from the actual memorandum of points and authorities. See supra note 120, at 13-19. 179. The court does not list these documents as redacted. But when the documents are downloaded they are clearly redacted. Monsanto v. DuPont (Jan. 19, 2010). 


\begin{tabular}{|c|c|c|}
\hline $\begin{array}{l}\text { 8. Defendants' MOTION for Partial Summary } \\
\text { Judgment on Counterclaim Count Nine Declar- } \\
\text { ing Claims } 1,2,115-119,122-125 \text { and } 145-148 \\
\text { of the ' } 247 \text { Re Patent Invalid Based on Nonen- } \\
\text { ablement }\end{array}$ & $\begin{array}{l}1099 \\
1100 \mathrm{~S} \\
1259 \mathrm{~S} \\
1282 \mathrm{~S}\end{array}$ & $\begin{array}{l}\text { 1321S MSJ } \\
\text { DENIED) }\end{array}$ \\
\hline $\begin{array}{l}\text { 9. Defendants' MOTION for Partial Summary } \\
\text { Judgment on Counterclaim Count Eight Find- } \\
\text { ing Noninfringement of the ' } 247 \text { Re Patent } \\
\text { Claims Reciting SEQ ID NO:3 }\end{array}$ & $\begin{array}{l}1105 \\
1107 \mathrm{~S} \\
1217 \mathrm{~S} \\
1287 \mathrm{~S}\end{array}$ & $\begin{array}{l}\text { 1381S MSJ } \\
\text { GRANTED }\end{array}$ \\
\hline $\begin{array}{l}\text { 10. Defendants' MOTION for Partial Summary } \\
\text { Judgment on Damages for Breach of Contract }\end{array}$ & $\begin{array}{l}1113 \\
1114 S \\
1211 S \\
1284 S\end{array}$ & $\begin{array}{l}1310 \text { S MSJ } \\
\text { GRANTED IN } \\
\text { PART AND } \\
\text { DENIED IN } \\
\text { PART } \\
\end{array}$ \\
\hline $\begin{array}{l}\text { 11. Defendants' MOTION for Partial Summary } \\
\text { Judgment on their License Affirmative Defense } \\
\text { and Counterclaim Count Twelve }\end{array}$ & $\begin{array}{l}1123 \mathrm{~S}, \\
1124 \mathrm{~S}, \\
1166 \mathrm{~S}, \\
1281 \mathrm{~S}\end{array}$ & $\begin{array}{l}\text { 1309S MSJ } \\
\text { DENIED }\end{array}$ \\
\hline $\begin{array}{l}\text { 12. Plaintiff's Motion for Summary Judgment } \\
\text { on Counts III, IV, V, VIII and IX of Monsan- } \\
\text { to's Complaint, on Defendants' License Af- } \\
\text { firmative Defense, and on Count XII of De- } \\
\text { fendants' Counterclaims }\end{array}$ & $\begin{array}{l}1128 \\
1129 \mathrm{~S} \\
1218 \mathrm{~S} \\
1292 \mathrm{~S}\end{array}$ & $\begin{array}{l}\text { 1308S MSJ } \\
\text { GRANTED IN } \\
\text { PART AND } \\
\text { DENIED IN } \\
\text { PART } \\
\text { (SEALED } \\
\text { MEM ORDER) }\end{array}$ \\
\hline $\begin{array}{l}\text { 13. Plaintiffs' MOTION for Partial Summary } \\
\text { Judgment on Defendants' Sixth and Seventh } \\
\text { Defenses and Counts IX and X of Defendants' } \\
\text { Counterclaims }\end{array}$ & $\begin{array}{l}1133, \\
1134 \mathrm{~S} \\
1268 \mathrm{~S} \\
1295 \mathrm{~S}\end{array}$ & $\begin{array}{l}1313 \mathrm{~S} \text { MSJ } \\
\text { DENIED }\end{array}$ \\
\hline $\begin{array}{l}\text { 14. Plaintiffs' MOTION for Partial Summary } \\
\text { Judgment on Defendants' Indefiniteness Alle- } \\
\text { gations }\end{array}$ & $\begin{array}{l}1136 \\
1138 \mathrm{~S} \\
1178 \mathrm{~S} \\
1301 \mathrm{~S} \\
\end{array}$ & $\begin{array}{l}\text { 1438S MSJ } \\
\text { GRANTED }\end{array}$ \\
\hline $\begin{array}{l}\text { 15. Plaintiffs' MOTION for Summary Judg- } \\
\text { ment on Defendants' Inequitable Conduct } \\
\text { Counterclaim }\end{array}$ & $\begin{array}{l}1137 \mathrm{~S} \\
1141 \mathrm{~S} \\
1222 \mathrm{~S} \\
1294 \mathrm{~S}\end{array}$ & $\begin{array}{l}\text { 1382S MSJ } \\
\text { GRANTED IN } \\
\text { PART AND } \\
\text { DENIED IN } \\
\text { PART } \\
\end{array}$ \\
\hline $\begin{array}{l}\text { 16. Plaintiffs' MOTION for Partial Summary } \\
\text { Judgment on Defendants' Defenses that the } \\
\text { Isolated and Recombinant DNA Claims of the } \\
\text { '247 Patent Are Invalid for Failure to meet the } \\
\text { Enablement and Written Description Require- } \\
\text { ments of } 35 \text { U.S.C. } 112\end{array}$ & $\begin{array}{l}1143 \\
1148 \mathrm{~S} \\
1206 \mathrm{~S} \\
1299 \mathrm{~S}\end{array}$ & $\begin{array}{l}\text { 1439S MSJ } \\
\text { GRANTED IN } \\
\text { PART AND } \\
\text { DENIED IN } \\
\text { PART }\end{array}$ \\
\hline $\begin{array}{l}\text { 17. Plaintiffs' MOTION for Summary Judg- } \\
\text { ment on Defendants' Improper Reissue Allega- } \\
\text { tions }\end{array}$ & $\begin{array}{l}1146 \\
1147 \mathrm{~S} \\
1186 \mathrm{~S} \\
1297 \mathrm{~S}\end{array}$ & $\begin{array}{l}\text { 1384S MSJ } \\
\text { DENIED }\end{array}$ \\
\hline
\end{tabular}




\section{APPENDIX B}

\section{Motions in Limine}

DE\#= Docket Entry Number in Pacer

$\mathrm{MD}=$ Missing Docket Entry

$\mathrm{S}=$ Filed Completely Under Seal

\begin{tabular}{|c|c|c|c|}
\hline & $\begin{array}{l}\text { DE\# } \\
\text { Mtn }\end{array}$ & $\begin{array}{c}\text { DE\# } \\
\text { Response }\end{array}$ & Title of Motion \\
\hline 1 & $1344 \mathrm{MD}$ & $1399 S$ & $\begin{array}{l}\text { Plaintiffs Motion in Limine to Exclude all Evidence } \\
\text { Regarding (1) Alleged Antitrust Conduct, Damages, } \\
\text { or Issues, (2) Unrelated Litigation Involving Differ- } \\
\text { ent Patents and Events, and (3) Saved-Seed } \\
\text { Litigation }\end{array}$ \\
\hline 2 & $1345 \mathrm{MD}$ & $1400 \mathrm{~S}$ & $\begin{array}{l}\text { Motion in Limine to Exclude Evidence that Plaintiffs } \\
\text { Seek to Extend the Life of the } 247 \text { RE Patent by } \\
\text { Requiring Post-Expiration Royalties }\end{array}$ \\
\hline 3 & $1346 \mathrm{MD}$ & $1398 \mathrm{~S}$ & $\begin{array}{l}\text { Monsanto's Motion in Limine to Exclude Evidence } \\
\text { Regarding Defendants' Hatch-Waxman Safe Harbor } \\
\text { Defense }\end{array}$ \\
\hline 4 & $1347 \mathrm{MD}$ & $1401 \mathrm{~S}$ & $\begin{array}{l}\text { Plaintiffs Motion in Limine to Exclude Expert Opin- } \\
\text { ions and Testimony Containing Legal Conclusions } \\
\text { or on Ultimate Issues of Invalidity for Lack of Ena- } \\
\text { blement, Written Description, or Incorrect } \\
\text { Inventorship }\end{array}$ \\
\hline 5 & $1350 \mathrm{MD}$ & $1402 S$ & $\begin{array}{l}\text { Memorandum in Opposition to Motion in Limine to } \\
\text { Exclude Evidence that Defendants No Longer Plan } \\
\text { to Commercialize an OGAT/RR Stacked Product }\end{array}$ \\
\hline 6 & $1351 \mathrm{MD}$ & $1403 \mathrm{~S}$ & $\begin{array}{l}\text { Plaintiffs Motion in Limine to Exclude Evidence and } \\
\text { Arguments Inconsistent with the Courts Sanctions } \\
\text { Order and the Courts Breach of Contract Orders }\end{array}$ \\
\hline 7 & 1353(MD) & $1423 \mathrm{~S}$ & $\begin{array}{l}\text { Defendants Motion in Limine No. } 1 \text { to Preclude } \\
\text { Plaintiffs from Referencing The Courts Order of } \\
\text { December } 21,2011\end{array}$ \\
\hline 8 & $1354 \mathrm{MD}$ & $1422 S$ & $\begin{array}{l}\text { Defendants' Motion in Limine No. } 2 \text { to Sequence } \\
\text { Trial on Willfulness and Damages After Trial on } \\
\text { Patent Liability }\end{array}$ \\
\hline 9 & $1355 \mathrm{~S}$ & $1426 \mathrm{~S}$ & $\begin{array}{l}\text { Defendants' Motion in Limine No. } 3 \text { to Preclude } \\
\text { Plaintiffs from Referencing the Parties' Contracts } \\
\text { and the Court's Summary Judgment Orders of June } \\
6,2012\end{array}$ \\
\hline 10 & $1356 \mathrm{MD}$ & $1427 \mathrm{~S}$ & $\begin{array}{l}\text { Motion in Limine No. } 71356 \text { to Preclude Defend- } \\
\text { ants from Creating a Negative Inference from Invo- } \\
\text { cation of the Attorney-Client Privilege }\end{array}$ \\
\hline 11 & $1357 \mathrm{~S}$ & $1429 \mathrm{~S}$ & $\begin{array}{l}\text { Defendants' Motion in Limine No. } 4 \text { for Clarifica- } \\
\text { tion that Inequitable Conduct is to be Tried to a Jury }\end{array}$ \\
\hline
\end{tabular}




\begin{tabular}{|c|c|c|c|}
\hline 12 & 1358MD & $1434 \mathrm{~S}$ & $\begin{array}{l}\text { Defendants' Motion in Limine No. } 51358 \text { to Pre- } \\
\text { clude Monsanto from Offering Evidence of Patent } \\
\text { Infringement Damages }\end{array}$ \\
\hline 13 & $1359 \mathrm{MD}$ & $1404 \mathrm{~S}$ & $\begin{array}{l}\text { Plaintiffs Motion in Limine to Exclude all Evidence } \\
\text { and Argument Regarding the Potential for Injunctive } \\
\text { Relief or Nominal Damages }\end{array}$ \\
\hline 14 & $1360 \mathrm{MD}$ & $1436 \mathrm{~S}$ & $\begin{array}{l}\text { Defendants Motion in Limine No. } 61360 \text { to Pre- } \\
\text { clude Monsanto from (1) Referencing Prior Litiga- } \\
\text { tion Between the Parties and Facts or Allegations at } \\
\text { Issue in Such Prior Litigation and (2) To Bar Evi- } \\
\text { dence of Any Settlement Discussions }\end{array}$ \\
\hline 15 & 1361(MD) & $1424 \mathrm{~S}$ & $\begin{array}{l}\text { Defendants' Motion in Limine No. } 71361 \text { to Pre- } \\
\text { clude to Exclude Plaintiffs from Arguing Patent } \\
\text { Infringement Under the Doctrine of Equivalents of } \\
\text { the SEQ ID NO:3 Claims }\end{array}$ \\
\hline 16 & $1362(\mathrm{MD})$ & $1412 \mathrm{~S}$ & $\begin{array}{l}\text { Defendants' Motion in Limine No. } 8 \text { to Preclude } \\
\text { Plaintiffs from Relying on "Secret Prior Art" and } \\
\text { Commercial Services as Evidence on Enablement }\end{array}$ \\
\hline 17 & $1363 \mathrm{MD}$ & $1411 \mathrm{~S}$ & $\begin{array}{l}\text { Defendants' Motion in Limine No. } 9 \text { to Set the Order } \\
\text { of Proof }\end{array}$ \\
\hline 18 & $1364 \mathrm{MD}$ & $1405 \mathrm{~S}$ & $\begin{array}{l}\text { Monsanto's Motion in Limine and Supporting } \\
\text { Memorandum to Preclude Defendants from Contra- } \\
\text { dicting or Challenging the Courts Claim Construc- } \\
\text { tion at Trial }\end{array}$ \\
\hline 19 & $1365 \mathrm{MD}$ & $1406 \mathrm{~S}$ & $\begin{array}{l}\text { Plaintiffs Motion in Limine to Exclude Evidence or } \\
\text { Allegations of Equitable Issues from the Jury Trial }\end{array}$ \\
\hline 20 & $1366 \mathrm{MD}$ & $1407 \mathrm{~S}$ & $\begin{array}{l}\text { Plaintiffs Motion in Limine to Exclude Evidence of } \\
\text { Two Categories of Subject Matter as Not Constitut- } \\
\text { ing Legal Prior Art Under } 35 \text { U.S.C. 102(e), 102(g) } \\
\text { OR } 103 \text { (Dkt. 1366)) }\end{array}$ \\
\hline 21 & $1367 \mathrm{MD}$ & $1408 \mathrm{~S}$ & $\begin{array}{l}\text { Plaintiffs Motion in Limine to Exclude all Evidence } \\
\text { Regarding Purported Yield Drag in Roundup Ready } \\
\text { Soybeans }\end{array}$ \\
\hline 22 & $1368 \mathrm{MD}$ & $1397 \mathrm{~S}$ & $\begin{array}{l}\text { Plaintiffs' Motion in Limine to Exclude All Evi- } \\
\text { dence Regarding Agent Orange and PCB Lawsuits }\end{array}$ \\
\hline 23 & $1369 \mathrm{MD}$ & $1416 \mathrm{~S}$ & $\begin{array}{l}\text { Monsanto's Motion to Exclude Testimony of Profes- } \\
\text { sor David C. Hricik (Dkt. 1369) }\end{array}$ \\
\hline 24 & $1371 \mathrm{MD}$ & $1417 \mathrm{~S}$ & $\begin{array}{l}\text { Plaintiffs' Daubert Motion to Exclude Testimony of } \\
\text { Dr. William Folk and Dr. Alan McHughen on "On } \\
\text { Sale Bar" and "Prior Public Use" }\end{array}$ \\
\hline 25 & $1372 \mathrm{MD}$ & $1410 \mathrm{~S}$ & $\begin{array}{l}\text { Monsanto's Motion in Limine to Exclude Testimony } \\
\text { of Dr. Alan McHughen for Failure to Comply with } \\
\text { Rule 26(a)(2)(B) (Dkt. } 1372\end{array}$ \\
\hline 26 & $1374 \mathrm{MD}$ & $1413 \mathrm{~S}$ & $\begin{array}{l}\text { Monsanto's Motion in Limine to Exclude Expert } \\
\text { Testimony Cumulative with Testimony of Elected } \\
\text { Experts }\end{array}$ \\
\hline 27 & 1376MD & $1414 \mathrm{~S}$ & $\begin{array}{l}\text { Monsanto's Motion in Limine to Exclude Evidence } \\
\text { Regarding Plastid Transformation }\end{array}$ \\
\hline
\end{tabular}


